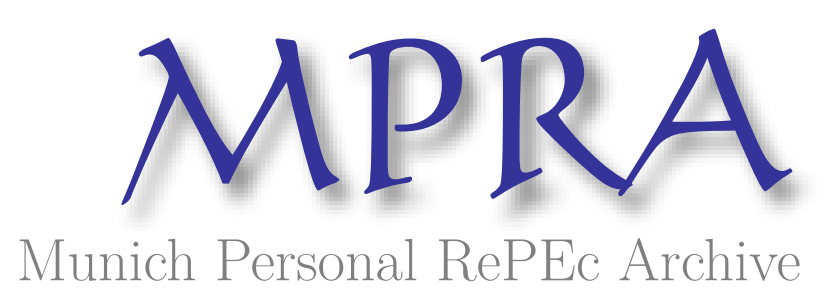

\title{
Causes of banking crises in modern world
}

Bojinov, Bojidar

Tsenov Academy of Economics, Svishtov, Bulgaria

21 May 2014

Online at https://mpra.ub.uni-muenchen.de/56034/

MPRA Paper No. 56034, posted 21 May 2014 22:35 UTC 


\title{
Causes of banking crises in modern world
}

\author{
Bojidar V Bojinov ${ }^{1}$
}

\begin{abstract}
The global financial crisis has highlighted the issue of the role and importance of the banking sector in a modern economy. It showed that the problems in the sector is the sector rarely, but rather transferred to the whole economy, impacting negatively on access to credit, payment mediation and smooth functioning of financial markets. This article is a critical analysis of the main reasons leading to further problems in the banking sector and the occurrence of a banking crisis.
\end{abstract}

Key words: banks, bank system, bank crises

JEL: G21

\section{Introduction}

Banking crises are costly to the economy crisis, not only because of the high direct cost saving, but also because of negative effects on the economy by limiting access to credit resources, negative impact on the price of government debt and those of securities of companies and possible impairment the national currency. A number of banking crises in different parts of the world and especially the U.S. mortgage crisis, which has grown into the world, reminded the contemporary economists that the economy is too complex and comprehensive science and everything in it is subject to mathematical modeling and prediction.

\section{Causes of banking crises}

The causes of banking crises can be classified into four main group international macro reasons, national macro reasons, causes the level of banking sector and reasons in the bank.

In recent years he started talking that one of the main prerequisites for the emergence and development of the global financial crisis global imbalances in the global economy ${ }^{2}$. The authors consider this process as a form of capital surpluses in countries net exporters of raw materials, goods and services from Bernanke phenomenon called "global glut of savings" ${ }^{3}$ leading to that exporting countries began to seek investment opportunities in foreign markets where to invest their savings, thereby impacting on the amount, direction and fluctuations of international credit and capital flows.

\footnotetext{
${ }^{1}$ The author is Professor in banking at Finance and Credit Dept. in Tsenov Academy of Economics, Svishtov, Bulgaria. Corresponding author: bobi@uni-svishtov.bg

This paper presents only the views of the author and in no way binds the Tsenov Academy of Economics, Svishtov, Bulgaria.

${ }^{2}$ Stulz, R., The Limits of Financial Globalization, Journal of Finance, 2005, 60 (4), 1595-1638., Buiter, W., Fiscal Expansions in Submerging Markets; the Case of the USA and the UK, ft.com/maverecon, February 52009

${ }^{3}$ Bernanke, B. "The global savings glut and the US current account deficit" Sandridge Lecture, Virginia Association of Economics, March 10, 2005
} 
Unfortunately, after the start of the global financial crisis, namely the direction and fluctuations in international capital flows played a negative impact and helped to spread and deepen the crisis. U.S. mortgage crisis and the subsequent collapse of securities based on mortgages scare foreign investors and encouraged them to sell their investments fire, which in turn further collapsed stock market prices.

Interesting is the view expressed by some authors that exporting countries consciously steered their available capital to developing economies, thereby turning their investments not only in high quality assets with secure income but also as a kind of insurance against problems in their countries ${ }^{4}$. Moreover, one of the leading countries net exporters, deliberate policy of undervaluing its own currency, respectively - to stimulate exports and employment, which led in financial circles to talk about the formation of new informal "Bretton Woods II"

As to the causes of banking crises of national macroeconomic level, to them we can treat deficiencies and structural problems in the economy, highly linked to foreign currencies, high levels of debt financing and external debt, large and sustained deficit in the current expense, monetary and fiscal policy, high state intervention in the economy, political instability. Should not be overlooked and underestimated and problems related to weaknesses and gaps in national legislation and especially deregulation of financial markets and the entry of non-bank financial institutions.

Attracting a high level of external funding, whether in the form of investments in financial assets, such as the case in the U.S., or in the form of debt financing, are also able to create a number of problems in the national economy. If the first case, the state can have very limited impact on the investment decisions of foreign investors, then in the case of debt financing opportunities for active management are significantly larger.

Currency risk can also be essential for the emergence and development of the banking crisis ${ }^{6}$. Of this risk can be complex and multidimensional. One of the possible events is associated with impairment of the national currency as a result of internal or external speculative attack or worsening of the national or international economic conditions. The manifestation of this risk may reflect problems in the banking sector, where there is an imbalance in the currency structure of assets and liabilities of commercial banks to generate immediate losses for banks and hence worsen its condition and its ability to cover the resulting liquidity demand ${ }^{7}$.

To macroeconomic conditions should take into account degree of export orientation of the country, respectively the status of its current account ${ }^{8}$. The large and sustained current account deficit creates prerequisites for significantly higher vulnerability of the economy to external shocks which can then reflect on the situation and the strength of the banking sector.

\footnotetext{
${ }^{4}$ Rodrik, D. "The social cost of foreign exchange reserves," Inernational Economic Journal, 20 (3), 2006, 253-266

${ }^{5}$ Dooley, M., D. Folkerts-Landau, P. Garber. "An Essay on the Revived Bretton Woods System" NBER Working Paper, No. 9971, 2003

6 Адамов, В. Р. Радков, А. Захариев. Валути и валутни системи Абагар, 2000, Nicolo, G., Р. Honohan, A. Ize, Dollarization of Bank Deposits: Causes and Consequences, Journal of Banking \& Finance, July 2005, 29 (7), 1697-1727, Hausmann, R., U. Panizza, E. Stein, Why Do Countries Float the Way They Float?, Journal of Development Economics, December 2001, 66 (2), 387-414

${ }^{7}$ Tarashev, N., "Currency Crises and the Informational Role of Interest Rates," discussion paper, Bank of International Settlement, 2005

8 Milesi-Ferretti, G., A.Razin. "Current Account Reversals and Currency Crises, Empirical Regularities," NBER Chapters, in: Currency Crises, pages 285-326 National Bureau of Economic Research, Inc., 2000, Kaminsky G., C. Reinhart, „The Twin Crises: The Causes of Banking and Balance-of-Payments Problems „International Finance Discussion Paper No. 544, Board of Governors of the Federal Reserve, 1996., Edwards, S., Thirty Years of Current Account Imbalances, Current Account Reversals, and Sudden Stops, IMF Staff Papers, 2004, 51(Special Issue), 1-49
} 
Factors usually state intervention has been linked by researchers to countries where the state has a greater involvement in the economy, including the banking sector. The traditional mechanism of state intervention in terms of its contribution banking problems, usually associated with the government ordered loans to certain businesses and industries. The global financial crisis of 2007 gave us another example of the negative impact of government intervention and its role in the distortion of market principles and to create conditions for banking crises. In case it comes to the state policy of the U.S. to boost its nationals to acquire immovable own. This policy was supported by government- sponsored agencies Frannie Mae and Frederick Mack, whose policy on access to resources, combined with an inadequate policy for risk assessment proved to be at the heart of the booming construction business and the mortgage market, which in turn led until the last mortgage crisis.

Although seemingly indirectly related to the banking system, fiscal policy of the state can indirectly affect its status. The most direct way to influence is through tax rates and / or the introduction of new types of taxes (e.g. tax on financial transactions) ${ }^{9}$. Usually in times of crisis and reduced revenue, some countries may be tempted to resort to "quick and easy money" from the banking system by any of the option or even a combination of them.

Fiscal tightening, combined with austerity in times of crisis can also impact negatively on the economy, and hence indirectly on the banking sector. Reduced government spending extra help reduce economic activity, increased unemployment, reduced living standards, thereby deteriorating business climate in the state. Decreased activity of companies and reduced income businesses and individuals is a major prerequisite for the share of problem loans, which in turn carries the problems of the real economy in the banking sector.

No less important factor considered here is the weaknesses and gaps in national legislation. Although at first glance this factor is associated with less developed economies or countries in transition, namely weaknesses and gaps in U.S. law were in the heart of the mortgage crisis, which later became global. The most common weaknesses in this area are the lack or partial perception of the world's leading standards for financial security and stability ${ }^{10}$.

Excessive liberalization and deregulation of financial markets, coupled with ineffective or no supervision are almost full warranty for the occurrence of problems in the banking sector in the foreseeable future ${ }^{11}$. Deregulation in recent decades contributes to increase competition in the banking sector and the entry of new players - non-bank financial institutions, a previously regulated and restricted to banks market. This in turn helps reduce the franchise value of banks and encouraged them to conduct aggressive marketing of its products and services in sometimes deliberately underestimating the risks associated with them $^{12}$.

Continuing the analysis of possible causes of banking crises, it is useful to pay more attention to those that occur at the financial sector level. Typically, these relate place and role of the central bank, including its conduct of banking supervision and monetary policy,

9 Honohan, P., „Banking Systems Failures in Developing and Transition Countries: Diagnosis and Prediction", BIS Working Paper No 39, BIS, Basle 1997

${ }^{10}$ Goldstein, M, P. Turner, Banking crises in emerging economies: origins and policy options, BIS Economic Papers, N 46, Bank for International Settlement, Basel, 1996

11 Reinhart, C., G. Kaminsky. "The center and the periphery: The globalization of financial turmoil," MPRA Paper 14100, University Library of Munich, Germany, 2008., Stulz, R., The Limits of Financial Globalization, Journal of Finance, 2005, 60 (4), 1595-1638., Demirgiic-Kunt, A., E. Detragiache, Financial Liberalization and Financial Fragility" in Gerard Caprio, Patrick Honohan, and Joseph E. Stiglitz, eds., Financial liberalization: How far, how fast?, Cambridge University Press Cambridge, 2000, pp. 96-122

${ }^{12}$ Davis, P., „Debt Financial Fragility and Systemic Risk", Oxford University press Inc. New York, USA. 1995 
financial liberalization and the related change in the structure of the financial sector and the entry of new players recently regulated markets, financial innovation and particularly different products securitization associated risks and ways of their market value, and the presence of distorted incentives through bonus system managers and employees in the banking system.

The central bank has always been the key to any economy, not least because it conducts monetary policy of the country and the fact that it is loaded with a commitment to "lender of last resort". The latter is directly related to ensuring the stability of the banking system by the possibility of a liquidity support to banks in difficulty, thus allowing them to avoid bankruptcy.

As for monetary policy, its purpose is the regulation of the economic cycle and business conditions in the economy while maintaining price stability and containing inflation ${ }^{13}$. A liberal monetary policy of cheap financing to commercial banks through low interest rates, combined with low levels of required reserves can help strengthen the banks' lending, respectively, reaching a situation of a credit boom ${ }^{14}$. The latter, in turn, appears to be an essential prerequisite for the emergence of bubbles of various assets in the economy mortgage, financial and others. The bursting of these speculative bubbles, in turn, is a prerequisite for a collapse in the prices of the segment of the economy and the deterioration of the loan portfolio of banks to finance the acquisition of overvalued assets.

Financial liberalization, especially in the U.S., dramatically changed the structure of the financial system, allowing significantly less regulated non-bank financial institutions, a significant proportion of the sector and take over some traditional classical banks ${ }^{15}$. And with regard to the stock market, the non-bank financial institutions almost completely dominate her. This process was further accelerated by the increasingly massive influx of financial innovations that allow financial institutions to offer an increasingly wide range of financial instruments, including derivatives and hybrid ones, each of which offers a different risk/return ratio ${ }^{16}$. Additional catalyst process proved and global surpluses in the international economy, looking for attractive investment opportunities.

Financial innovation and, in particular, the securitization of various types of assets allowed outside the provision of attractive investment opportunities, and the ability of banks to limit the risks borne by them and transfer them to other market participants ${ }^{17}$. Besides an effective tool to minimize the risks undertaken by banks, securitization proved to be very attractive channel for financing of its active operations by means of the stock market, thus reducing the importance and role of traditional bank deposits. Possibility of building a new synthetic tools allow the construction of many derivative securities, ie expand investment choices to those seeking investment opportunities by offering securities with different types and levels of risk.

${ }^{13}$ Gambacorta, L. "Monetary Policy and the Risk-Taking Channel." BIS Quarterly Review 2009 (December): 43-53, 2009., Schularick, M., A. Taylor, Credit Booms Gone Bust: Monetary Policy, Leverage Cycles and Financial Crises, 1870-2008, NBER Working Papers 15512, National Bureau of Economic Research November 2009

14 Taylor, J. Getting Off Track: How Government Actions and Interventions Caused, Prolonged, and Worsened the Financial Crisis, Hoover Institution Press, Stanford, March 2008, Bank for International Settlements. 78th Annual Report 2008

${ }^{15}$ Buiter, W., Lessons from the 2007 Financial Crisis, Background Paper Submitted to the UK Treasury Select Committee, December 11, 2007., Bernanke, B., Four Questions about the Financial Crisis" speech at Morehouse College, Atlanta, Georgia, April 14. 2009

${ }^{16}$ Mishkin, F., Global Financial Turmoil and the World Economy,"Caesarea Forum of the Israel Democracy Institute, Eilat, Israel, July 22008

${ }^{17}$ Demirguc-Kunt, A., L. Serven, Are the Sacred Cows Dead?: Implications of the Financial Crisis for Macro and Financial Policies, World Bank Policy Research Working Paper no. 4807, January. 2009 
Unfortunately, the processes of securitization led to a sharp increase in asymmetric information $^{18}$. If classic mortgage, the bank has an incentive to explore in detail the status, history and behavior of their borrowers, as it assumes it is exposed to the full repayment of the loan, then as in the securitization of those mortgages, the bank began to lose these incentives. This is due to the fact that the bank transfer through securitization risk those same mortgages to the holders of these securities in exchange for the risk she gets immediate profitability.

Here we look for a link between the bonus system of financial institutions and the extraordinary risk-taking. Over the last decade the financial sector more widely perceived view that the bonus system managers and employees must be directly linked to the financial performance of the institution ${ }^{19}$. Unfortunately, such a view leads to perverse incentives and excessive risk-taking for short-term profit.

The global financial crisis of 2007 put on the agenda the question of the role, place and regulation of rating agencies in the modern world. We usually associate this type of institutions with expert, objective and impartial evaluation of the various aspects of our life assets, companies, and countries. Until the crisis no one questioning their assessment, but encountered financial problems raised a number of issues before them. One of the first and immediate questions was why the market for one class of financial instruments, according to them, collapsed in such a way that the effects were felt around the world? Unfortunately, the answer was that their models for forecasting and evaluation do not work adequately. This can partly be explained by the fact that many of the new financial instruments lacked any historical basis for their behavior. And if we consider also that in most models for forecasting missing scenario of global market collapse, then the picture will be even more complete ${ }^{20}$.

Continuing review of causes that can lead to the occurrence of banking crises should not be underestimated and those that arise in individual banks. Perhaps one of the oldest historical reasons that can lead to problems in individual banking institution that is its susceptibility to liquidity problems ${ }^{21}$. This is mainly due to the fact that banks usually finance their long-term active operations with deposits, i.e. short-term borrowings. It is this difference in timing of active and passive banking operations are potential prerequisite for the emergence of liquidity problems in the event of increased liquidity pressure from depositors. Liquidity problems may arise in cases of impairment of the national currency, combined with inadequate currency structure of active and passive banking operations, as well as the quality of the loan portfolio of banks.

In recent years a steady trend of increasing leverage in the financial sector. In seeking to achieve higher rates of return on their investments, banking institutions reached a level of $1: 35^{22}$. The problem arises in the case of deterioration of economic conditions or a collapse in the prices of certain assets in which the Bank may be in a situation that cannot meet their obligations and have to resort to emergency liquidation of assets.

${ }^{18}$ Gorton, G., The Panic of 2007. NBER Working Paper Series, Vol. w14358, 2008., ${ }^{18}$ De Michelis, A., Overcoming the Financial Crisis in the United States, OECD Economics Department Working Paper no. 669, February 2009

${ }^{19}$ Roberts, R. Gambling with other people's money. How perverted incentives caused the financial crisis. Arlington, Va., Mercatus Centre at George Mason University.2010

20 Skreta, V., L. Veldkamp. "Ratings shopping and asset complexity: A theory of ratings inflation," Journal of Monetary Economics, Elsevier, vol. 56(5), pages 678-695, July, 2008

${ }^{21}$ Вътев, Ж. Анализ на банковата дейност, АБАГАР, 1998. Goldstein, M., P. Turner, „Banking Crises in Emerging Economies: Origin and Policy Options", BIS Economic Papers No. 46, Bank for International Settlements, Basle.1996

22 Adrian, T., H. Shin. "Liquidity and financial cycles", paper presented at the 6th BIS Annual Conference, Brunnen, 18-19 June. 2007., Schularick, M., A. M. Taylor, Credit Booms Gone Bust: Monetary Policy, Leverage Cycles and Financial Crises, 1870-2008, NBER Working Papers 15512, National Bureau of Economic Research November 2009 
Increase competition in the banking sector is a precondition for serious understatement, but some cases - and the deliberate elimination of certain risks, to extend or maintain market share or position of the bank ${ }^{23}$. Unfortunately, this process can be worsened by turning off solutions in poor management practices leading to inadequate risk assessment and excessive risk-taking by financial institutions. A typical example of this may indicate the securitization of mortgage loans in the U.S., where banks lost all incentive to adequately assess the credit risk as fully transferring the owners of the securities based on mortgages ${ }^{24}$.

Competition has a negative impact on the financial performance of institutions by reducing their profit margin. Thus, banks reduce their capital buffer by which can meet the deterioration of economic conditions or unexpected financial losses.

In recent years we are increasing number of cases of fraud in the banking sector ${ }^{25}$. Although in most cases are minor jobs at low level, not missing cases when it comes to large amounts of funds. A typical example is the case of Societe Generale, which in 2008 reported a loss of over $\$ 7$ billion as a result of fraud by its employees.

\section{Conclusion}

In normal times, banks contribute to the accelerated development of the economy and raise living standards in general, but the difficulties in the banking sector and subsequent failures cause serious negative consequences not only for the banking sector and directly affected companies and investors, but also for the rest of the economy. The study of banking crises is extremely important for their early detection and application of preventive measures to reduce or eliminate their effects.

Different theoretical directions give different explanation banking crises, ranging from their relationship with the business cycle, money and circulation, pass through "rational expectations", "euphoria" and "rational speculative bubble" to get to the asymmetric information and uncertainty. The most common causes of banking crises can be classified into four main group international macro reasons, national macro reasons, causes the level of banking sector and reasons in the bank.

\section{References}

1. Адамов, В. и др. Валути и валутни системи. Абагар, 2000 (Adamov, V. et. al. Currencies and currency systems. ABAGAR, V. Tarnovo, 2000)

2. Вътев, Ж. и др.Анализ на банковата дейност, АБАГАР, 1998 (Vatev, J. et. al. Analysis of bank activities. ABAGAR, V. Tarnovo, 1998)

3. Adrian, T., H. Shin. "Liquidity and financial cycles", paper presented at the 6th BIS Annual Conference, Brunnen, 18-19 June. 2007

4. Bernanke, B. "The global savings glut and the US current account deficit," Sandridge Lecture, Virginia Association of Economics, March 10, 2005

5. Bernanke, B., Four Questions about the Financial Crisis" speech at Morehouse College, Atlanta, Georgia, April 14. 2009

${ }^{23}$ Davis, P., „Debt Financial Fragility and Systemic Risk", Oxford University press Inc. New York, USA. 1995

${ }^{24}$ Trichet, J., "What Lessons Can be Learned from the Economic and Financial Crisis?," speech at the 5e Recontres de l'Entreprise Europeenne, Paris, France, 17 March 2009

${ }^{25}$ Caprio, G., P. Honohan. "Banking Crises," Center for Development Economics 2008-09, Department of Economics, Williams College, 2008 
6. Buiter, W., Fiscal Expansions in Submerging Markets; the Case of the USA and the UK, ft.com/maverecon, February 52009

7. Buiter, W., Lessons from the 2007 Financial Crisis, Background Paper Submitted to the UK Treasury Select Committee, December 11, 2007

8. Caprio, G., P. Honohan. "Banking Crises," Center for Development Economics 200809, Department of Economics, Williams College, 2008

9. Davis, P., „Debt Financial Fragility and Systemic Risk", Oxford University press Inc. New York, USA. 1995

10. De Michelis, A., Overcoming the Financial Crisis in the United States, OECD Economics Department Working Paper no. 669, February 2009

11. Demirgiic-Kunt, A., E. Detragiache, Financial Liberalization and Financial Fragility" in Gerard Caprio, Patrick Honohan, and Joseph E. Stiglitz, eds., Financial liberalization: How far, how fast?, Cambridge University Press Cambridge, 2000, pp. 96-122

12. Demirguc-Kunt, A., L. Serven, Are the Sacred Cows Dead?: Implications of the Financial Crisis for Macro and Financial Policies, World Bank Policy Research Working Paper no. 4807, January. 2009

13. Dooley, M., D. Folkerts-Landau, P. Garber. "An Essay on the Revived Bretton Woods System," NBER Working Paper, No. 9971, 2003

14. Edwards, S., Thirty Years of Current Account Imbalances, Current Account Reversals, and Sudden Stops, IMF Staff Papers, 2004, 51(Special Issue), 1-49

15. Gambacorta, L. "Monetary Policy and the Risk-Taking Channel." BIS Quarterly Review 2009 (December): 43-53, 2009

16. Goldstein, M, P. Turner, Banking crises in emerging economies: origins and policy options, BIS Economic Papers, N 46, Bank for International Settlement, Basel, 1996

17. Gorton, G., The Panic of 2007. NBER Working Paper Series, Vol. w14358, 2008

18. Hausmann, R., U. Panizza, E. Stein, Why Do Countries Float the Way They Float?, Journal of Development Economics, December 2001, 66 (2), 387-414

19. Honohan, P., „Banking Systems Failures in Developing and Transition Countries: Diagnosis and Prediction", BIS Working Paper No 39, BIS, Basle 1997

20. Kaminsky G., C. Reinhart, „,The Twin Crises: The Causes of Banking and Balance-ofPayments Problems „International Finance Discussion Paper No. 544, Board of Governors of the Federal Reserve, 1996

21. Milesi-Ferretti, G., A.Razin. "Current Account Reversals and Currency Crises, Empirical Regularities," NBER Chapters, in: Currency Crises, pages 285-326 National Bureau of Economic Research, Inc., 2000

22. Mishkin, F., Global Financial Turmoil and the World Economy,"Caesarea Forum of the Israel Democracy Institute, Eilat, Israel, July 22008

23. Nicolo, G., P. Honohan, A. Ize, Dollarization of Bank Deposits: Causes and Consequences, Journal of Banking \& Finance, July 2005, 29 (7), 1697-1727

24. Reinhart, C., G. Kaminsky. "The center and the periphery: The globalization of financial turmoil," MPRA Paper 14100, University Library of Munich, Germany, 2008

25. Roberts, R. Gambling with other people's money. How perverted incentives caused the financial crisis. Arlington, Va., Mercatus Centre at George Mason University.2010

26. Rodrik, D. "The social cost of foreign exchange reserves," Inernational Economic Journal, 20 (3), 2006, 253-266

27. Schularick, M., A. M. Taylor, Credit Booms Gone Bust: Monetary Policy, Leverage Cycles and Financial Crises, 1870-2008, NBER Working Papers 15512, National Bureau of Economic Research November 2009 
28. Skreta, V., L. Veldkamp. "Ratings shopping and asset complexity: A theory of ratings inflation," Journal of Monetary Economics, Elsevier, vol. 56(5), pages 678-695, July, 2008

29. Stulz, R., The Limits of Financial Globalization, Journal of Finance, 2005, 60 (4), 1595-1638

30. Tarashev, N., "Currency Crises and the Informational Role of Interest Rates," discussion paper, Bank of International Settlement, 2005

31. Taylor, J. Getting Off Track: How Government Actions and Interventions Caused, Prolonged, and Worsened the Financial Crisis, Hoover Institution Press, Stanford, March 2008, Bank for International Settlements. 78th Annual Report 2008

32. Trichet, J., "What Lessons Can be Learned from the Economic and Financial Crisis?," speech at the 5e Recontres de l'Entreprise Europeenne, Paris, France, 17 March 2009 